\title{
HUBUNGAN ANTARA KEPEMIMPINAN, MOTIVASI KERJA DAN KOMITMEN ORGANISASI DENGAN DISIPLIN KERJA APARATUR SIPIL NEGARA
}

\author{
Irmansyah Wahyudin ${ }^{1}$, Jarnawi Afgani Dahlan ${ }^{3}$ \& Edi Mulyadi ${ }^{2}$ \\ Email : irmansyahwahyudin@yahoo.co.id \\ ${ }^{1}$ Mahasiswa Program Pascasarjana Ilmu Administrasi - UNIS Tangerang. \\ ${ }^{2}$ Program Pascasarjana Ilmu Administrasi - UNIS Tangerang \\ ${ }^{3}$ Departemen Pendidikan Matematika - UPI
}

\begin{abstract}
Abstrak
Tujuan dari penelitian ini adalah untuk mengetahui hubungan antara Kepemimpinan, Motivasi Kerja dan Komitmen Organisasi dengan Disiplin Kerja Aparatur Sipil Negara Kecamatan di Kota Tangerang. Penelitian ini menggunakan metode kuantitatif dengan penelitian survey untuk menjawab rumusan masalah dan membuktikan hipotesis penelitian yang diajukan, adapun instrumen penelitiannya berbentuk kuesioner yang dibangun dari penjabaran indikator - indikator tiap variabel dengan alat ukur skala Likert. Populasi penelitian ini adalah Aparatur Sipil Negara di 13 Kecamatan di Kota Tangerang yang berjumlah 920 orang, adapun penentuan sampel penelitian sebanyak 90 orang dengan menggunakan tehnik cluster sampling yang diukur secara statistika menggunakan rumus Slovin. Sebelum dilakukan analisis, instrumen diuji validitas dan realibilitasnya. Teknik analisis yang digunakan dalam penelitian ini meliputi teknik analisis korelasi pearson product moment, analisis korelasi berganda, analisis koefisien determinasi dan teknik analisis regresi sederhana dan regresi berganda. Hasil pengujian hipotesis dari penelitian ini menyatakan bahwa terdapat hubungan signifikan secara statistik antara kepemimpinan dengan disiplin kerja ASN Kecamatan di Kota Tangerang yang positif sebesar 0,727. Terdapat hubungan signifikan secara statistik antara motivasi kerja dengan disiplin kerja ASN Kecamatan di Kota Tangerang yang positif sebesar 0,842. Terdapat hubungan signifikan secara statistik antara komitmen organisasi dengan disiplin kerja ASN Kecamatan di Kota Tangerang yang positif sebesar 0,660. Terdapat hubungan signifikan secara statistik antara kepemimpinan, motivasi kerja dan komitmen organisasi secara bersama - sama dengan disiplin kerja ASN Kecamatan di Kota Tangerang yang positif sebesar 0,889.

Kata Kunci : Kepemimpinan, Motivasi Kerja, Komitmen Organisasi, Disiplin Kerja, Aparatur Sipil Negara

Abstract

The purpose of this research is to know the relationship between leadership, work motivation and organizational commitment with the work discipline of civil state apparatus in Tangerang city. This research uses quantitative methods with survey research to answer the problem formulation and to prove the research hypothesis proposed, the research instrument in the form of questionnaires constructed from the description of indicators - Each variable with the Likert scale gauge. The population of this research is the civil state apparatus in 13 sub-districts in Tangerang city amounting to 920 people, as well as the determination of research samples of 90 people using sampling cluster techniques measured in statistics using
\end{abstract}

Vol 2, No 1 (2020) 
the formula Slovin. Prior to analysis, the instrument tested its validity and realibility. The analytical techniques used in this research include the Pearson Product Moment correlation analysis technique, multiple correlation analysis, coefficient of determination and simple regression analysis techniques and multiple regression analyses. The results of the hypothesis testing of the study stated that there was statistically significant link between the leadership with the working discipline of ASN sub district in Tangerang City which positively amounted to 0,727. There is a statistically significant link between work motivation and work discipline of ASN sub district in Tangerang City which positively amounted to 0,842. There is a statistically significant link between the organization's commitment to the working discipline of ASN sub district in Tangerang City which positively amounted to 0,660. There is a statistically significant link between leadership, work motivation and organizational commitment together with the working discipline ASN sub district in Tangerang City which positively amounted to 0,889 .

Keywords: leadership, Work Motivation, organizational commitment, work discipline, of civil state apparatus

\section{A. Pendahuluan}

Pegawai Pemerintahan atau dengan kata lain disebut Aparatur Sipil Negara (ASN) merupakan tulang punggung tercapainya keberhasilan pelaksanaan pembangunan nasional dan daerah. Dengan kata lain, untuk mewujudkan masyarakat yang adil serta makmur sesuai dengan amanat Pancasila dan Undang - Undang Dasar Tahun 1945 sangat bergantung kepada Profesionalitas ASN. Professional dalam arti bahwa setiap ASN harus memiliki integritas kepada bangsa dan Negara Indonesia, serta bertanggung jawab dan memiliki keinginan untuk bekerja dengan baik atas setiap tugas yang diberikan oleh Negara. Hal ini sejalan dengan apa yang diamanaatkan dalam Undang - undang No. 5 Tahun 2014 tentang Aparatur Sipil Negara, dimana secara garis besar menerangkan bahwa ASN harus memiliki Integritas, Profesional, terbebas dari intervensi kepentingan politik dan bersih dari praktik - praktik seperti Korupsi, Kolusi dan Nepotisme.

Tantangan zaman di Era Globalisasi dan Revolusi 4.0 mendorong ASN untuk bekerja untuk melayani masyarakat dengan maksimal. Pelayanan yang terbaik tidak akan dapat terlaksana apabila tidak ada keteraturan dan disiplin kerja dalam setiap pelaksanaan tugas. Disiplin kerja merupakan modal utama bagi ASN dalam rangka melaksanakan tugas serta tanggungjawabnya untuk menjalankan pengabdian kepada bangsa dan negara, akan tetapi akhirakhir ini disiplin kerja ASN sangat memperihatinkan, hal ini dapat dilihat dengan masih banyaknya pelanggaran terhadap Disiplin Kerja ASN dalam melaksanakan pelayanan kepada masyarakat, yang mengakibatkan menurunnya kepercayaan dari masyarakat. Hal ini sejalan dengan apa yang disampaikan Bima Haria Wibisana selaku Kepala Badan Kepegawaian Negara Republik Indonesia, menyatakan bahwa : "Badan Kepegawaian Negara Republik Indonesia mengungkapan ada 2.674 Pegawai Negeri Sipil yang kasusnya sudah berkekuatan hukum tetap (inkrah) atau terbukti melakukan Korupsi. Namun, dari 2.674 PNS yang terbukti korupsi baru sekitar 317 PNS 
yang dipecat. Sementara sisanya 2.357 PNS masih aktif bekerja. Data ini masih akan terus berkembang sesuai dengan verifikasi dan validasi lanjutan. (sindonews.com/2018)"

Implementasi penegakan aturan Disiplin terhadap ASN berdasarkan Peraturan Pemerintah Nomor 53 Tahun 2010 dinilai masih belum mengatur secara tegas serta rinci berkaitan dengan Disiplin ASN. Sebagaimana dinyatakan Lina Mifthaul Jannah yang merupakan Pakar Administrasi Publik dari Universitas Indonesia bahwa : "Peraturan Pemerintah tentang Disiplin ASN hanya berbicara tentang jenis sanksi yaitu ringan, sedang dan berat, namun pelanggarannya didefinisikan oleh masing - masing Pejabat Pembina Kepegawaian (PPK). Ada pelanggaran yang seharusnya mendapat sanksi berat, tapi hanya diberikan teguran. Ada yang terkena narkoba lalu direhabilitasi, dan setelah itu kembali lagi bekerja. Kelonggaran - kelonggaran inilah yang dinilai membuat banyak ASN tidak begitu khawatir melakukan pelanggaran. Terlebih lagi, jika memiliki kedekatan dengan PPK, dipastikan lolos dari sanksi yang berat. Tanpa pengaturan Disiplin ASN yang tegas dapat dipastikan sulit mewujudkan ASN yang Profesional. (sindonews.com/2018)."

Peran dari Pejabat Pembina Kepegawaian dalam mengeluarkan keputusan pemberian sanksi hukum terhadap pelanggaran disiplin oleh ASN merupakan suatu keharusan. Permasalahan di atas dapat di atasi, pemerintah sudah saatnya melalui pimpinan unit kerja masing-masing diharapkan dapat menjalankan aturanaturan mengenai disiplin kerja yang telah ditetapkan dengan efektif dan sebaik-baiknya menyesuaikan dengan jenis pelanggarannya, dimulai dari pemberian sanksi administrasi, penundaan kenaikan pangkat atau golongan, penurunan dari jabatan sampai pemberhentian sebagai ASN dengan hormat maupun dengan tidak hormat, sehingga diharapkan pada masa yang akan datang terwujud peningkatan dari kepercayaan masyarakat akan terpenuhinya pelayanan public.

Permasalahan Disiplin Kerja ASN menjadi perhatian utama dari Pemerintah Kota Tangerang sebagaimana tertuang dalam visi dan misi Walikota, yaitu untuk mewujudkan tata pemerintahan yang baik, akuntabel, dan transparan didukung dengan struktur birokrasi yang berintegritas, kompeten dan profesional. Dengan ditetapkannya Peraturan Walikota Tangerang Nomor 3 Tahun 2018 tentang Hari Kerja, Jam Kerja dan Apel Pagi ASN di Kota Tangerang didalamanya memuat aturan bahwa setiap ASN di Kota Tangerang berkewajiban untuk melaksanakan Apel Pagi setiap hari kerja pada pukul 07:30 WIB di unit kerja masing-masing. Bagi ASN yang melanggar aturan tersebut akan dikenakan sanksi potongan tunjangan prestasi kerja sebesar $1 \%$ sedangkan bagi yang tidak hadir tanpa adanya keterangan dikenai sanksi potongan sebesar 3\% dari tunjangan prestasi kerja. Dalam rangka membentuk ASN yang berkualitas dibutuhkan penerapan Disiplin Kerja yang tinggi, oleh sebab itu Pemerintah Kota Tangerang membuat peraturan yang bertujuan untuk menciptakan ASN yang berdisiplin tinggi dalam rangka mewujudkan visi dan misi yang telah 
ditetapkan.

Kecamatan sebagai ujung tombak pelayanan dimana ASN Kecamatan merupakan unit pelayan langsung yang berhubungan dengan masyarakat. Berdasarkan Data dari Bagian Pemerintahan Sekretariat Daerah Kota Tangerang, Pemerintah Kota Tangerang terbagi menjadi 13 Kecamatan. Kecamatan sebagai pilar utama pelayanan masyarakat Kota Tangerang, ASN Kecamatan harus mampu memberikan pelayanan prima, memiliki kualitas kerja yang tinggi dan dituntut untuk memiliki sikap moral yang baik kepada masyarakat, maupun untuk organisasi. Untuk itu, ASN Kecamatan harus menerapkan disiplin kerja yang tinggi. Namun demikian, berdasarkan pengamatan peneliti pada beberapa Kecamatan di Kota Tangerang masih ditemukan pelanggaran disiplin kerja yang dilakukan oleh ASN Kecamatan, khususnya Pelanggaran terhadap Apel Pagi.

Permasalahan selanjutnya yang ditemukan berdasarkan pengamatan peneliti adalah pelanggaran terhadap Jam Kerja. Sebagaimana diketahui Jam Kerja ASN Kecamatan di Kota Tangerang adalah Senin - Jum'at, dimulai pada pukul 07.30 s/d 16.00 , dengan waktu istirahat pada pukul 12.00 s/d 13.00. Namun demikian, berdasarkan pengamatan peneliti pada waktu Jam Kerja di beberapa Kecamatan ditemukan petugas pelayanan tidak pada tempatnya dan waktu buka Loket Pelayanan pun tidak tepat pada waktunya sesuai dengan aturan yang telah ditetapkan. Hal ini menyebabkan pelayanan masyarakat yang kurang memuaskan dikarenakan rendahnya kesadaran dan tanggung jawab untuk melaksanakan tugas yang pada akhirnya bermuara pada kinerja ASN. Dapat diasumsikan bahwa rendahnya kesadaran dan tanggung jawab ASN Kecamatan terhadap tugas disebabkan karena kejenuhan dalam pekerjaan (tidak ada motivasi kerja), minimnya loyalitas terhadap pimpinan dan organisasi (komitment organisasi yang rendah) dan Lingkungan Organisasi yang tidak mendukung (bermasalah dengan pimpinan atau rekan kerja).

Permasalahan - permasalahan yang dipaparkan di atas seperti Disiplin Waktu dimana masih banyak ASN Kecamatan di Kota Tangerang yang terlambat masuk kerja dan keluar pada saat jam kerja, Disiplin Peraturan dimana masih terdapat ASN Kecamatan di Kota Tangerang yang tidak mengikuti apel dan tidak menandatangani absen yang disediakan dan Disiplin Tanggung jawab dimana masih ada ASN Kecamatan di Kota Tangerang yang tidak menjalankan tugas dan pekerjaan sesuai dengan standar waktu yang diperintahkan. Sehingga perlu dilakukan penanganan yang serius, bila tidak akan menghambat pelaksanaan pelayanan masyarakat dan tugas - tugas pokok yang telah dilimpahkan Walikota kepada Camat selaku pemimpin di Kecamatan. Disisi lain kebijakan Walikota melalui Prioritas Pembangunan Daerah yaitu untuk tata kelola dan tata kerja birokrasi Pemeritahan Kota Tangerang yang baik dan bersih akan sulit untuk terwujud. Keadaan di atas dapat ditarik suatu dugaan bahwa Peraturan Walikota Tangerang Nomor 3 Tahun 2018 tentang Hari Kerja, Jam Kerja dan Apel Pagi ASN di Kota Tangerang khususnya yang terjadi pada ASN Kecamatan di Kota 
Tangerang belum berjalan dengan efektif dikarenakan pemotongan tunjangan kinerja tersebut belum memberikan efek disiplin yang signifikan.

Berdasarkan uraian dan data yang telah di sampaikan, pada kesempatan ini peneliti tertarik untuk mengungkap lebih dalam mengenai variabel - variabel yang mempunyai hubungan dengan Disiplin Kerja ASN Kecamatan di Kota Tangerang. Oleh karena tujuan dalam penelitian ini adalah mengkaji hubungan antara kepemimpinan, komitmen organisasi dengan dengan disiplin kerja aparatur sipil negara.

\section{Kajian Teori}

\section{Kepemimpinan}

Syafii (2015:17) mengatakan bahwa : "Kepemimpinan dapat diartikan sebagai kemampuan seseorang untuk membujuk dan mempengaruhi orang lain agar melakukan tindakan pencapaian tujuan bersama. sehingga hal tersebut merupakan awal struktur dan pusat proses kelompok". Lebih lanjut Farland menjelaskan "kepemimpinan merupakan sebuah proses proses yang didalamnya pemimpin memberi perintah atau pengaruh, bimbingan atau proses mempengaruhi pekerjaan orang lain dalam memilih dan mencapai tujuan yang telah ditetapkan" (Danim, 2010:6). Senada dengan pendapat Farland, Ordway Tead dikutip Kartono (2010:57) mendefinisikan kepemimpinan sebagai "Kegiatan mempengaruhi orang-orang agar mereka mau bekerja sama untuk mencapai tujuan yang diinginkan".

Mencermati pendapat para ahli di atas, dapat dikatakan bahwa kepemimpinan sebagai perilaku seseorang pemimpin yang pada setiap aktivitasnya berusaha membimbing dan mengarahkan anggota - anggota kelompoknya dan dapat mencapai tujuan yang ditetapkan, maka hal ini merupakan kepemimpinan yang sukses. Kepemimpinan merupakan sesuatu yang mempunyai pengaruh besar dan sentral dalam organisasi. Dengan kata lain, keberhasilan suatu organisasi untuk mencapai suatu tujuan sangat dipengaruhi oleh kepemimpinan yang efektif.

Dalam studi kepemimpinan, banyak literatur yang membahas pendekatan terhadap kepemimpinan, hal ini menunjukkan bahwa banyak faktor yang dapat mempengaruhi kepemimpinan, baik faktor yang berasal dari dalam diri pemimpin, seperti sifat, sikap, motivasi dan lain lain, maupun faktor dari luar diri pemimpin, seperti hubungan sosial, keadaan kelompok dan lain - lain. Seiring dengan rumusan masalah pada penelitian ini, maka pembahasan kepemimpinan dibatasi pada pendekatan perilaku pemimpin dalam hal ini sifat yang dimiliki oleh pemimpin.

Teori yang berkaitan dengan kepemimpinan, sebagaimana diungkapkan oleh Davis dikutip Thoha (2014:287-288) mengungkapkan, bahwa terkait dengan teori sifat, maka syarat kepemimpinan harus memiliki 4 sifat, yaitu :

1. Kecerdasan.

Pada umumnya hasil penelitian membuktikan bahwa pemimpin mempunyai tingkat kecerdasan yang lebih tinggi dibandingkan dengan yang dipimpin. Namun demikian, yang sangat menarik dari penelitian tersebut ialah pemimpin 
tidak bisa melampaui terlalu banyak dari kecerdasan pengikutnya.

2. Kedewasaan dan keluasan hubungan sosial.

Pemimpin cenderung menjadi matang dan mempunyai emosi yang stabil, serta mempunyai perhatian yang luas terhadap aktivitasaktivitas sosial. Dia mempunyai keinginan menghargai dan dihargai.

3. Motivasi diri dan dorongan berprestasi.

Para pemimpin mempunyai motivasi yang kuat untuk berprestasi. Mereka berkerja berusaha mendapatkan penghargaan yang intriksik dibandingkan dari yang ekstrinsik.

4. Sikap-sikap

kemanusiaan.

Pemimpin yang sukses adalah yang mau mengakui harga diri dan kehormatan para pengikutnya dan mampu berpihak kepadanya.

Dalam kaitannya dengan sifat pemimpin, lebih lanjut diungkapkan oleh Ghiselli dikutip Suharsono (2012:131) juga menjelaskan teorinya tentang sifat-sifat yang wajib dimiliki oleh pemimpin, yaitu:

1. Kemampuan

pengawasan

(supervisory ability)

Kemampuan pemimpin di wewenangnya sebagai pengawas atau melaksanakan fungsi management serta melakukan pengawasan dan bimbingan pekerjaan kepada orang yang dipimpinnya.

2. Kesuksesan dalam Pekerjaan

Keinginan untuk sukses dan jiwa bertanggung jawab harus muncul dalam diri pemimpin.

3. Intelektual

Seorang pemimpin mampu mengambil keputusan dan kebijakan yang tepat, serta mampu memunculkan pemikiran yang kreatif dan inovatif serta pemikiran yang luas.

4. Ketegasan

Pemimpin Mampu untuk memecahkan permasalahan yang ada dengan bijak dan tepat.

5. Percaya Diri

Pemimpin harus mempunyai kepercayaan terhadap pandangan dirinya bahwa dirinya mampu menghadapi masalah.

6. Inisatif

Seorang pemimpin harus mampu bertindak dan tidak terpaku pada satu cara penyelesaian masalah.

\section{Motivasi Kerja}

Motivasi adalah kekuatan yang ada dalam seseorang yang dapat meningkatkan kesadaran untuk bersikap atau berperilaku untuk melakukan tindakan. Sebagaimana diungkapkan French dalam Irawan (2002:235) bahwa "motivasi adalah hasrat atau keinginan seseorang meningkatkan upaya untuk mencapai target atau hasil". Lebih lanjut, menurut Thoha (2014:253) mengungkapkan bahwa "motivasi dapat diartikan sebagai faktor pendorong seseorang untuk melakukan sebuah kegiatan dalam mencapai tujuan. Motivasi sebagai sebuah kekuatan yang dapat membuat seseorang berkeinginan untuk memulai dan menjaga kondisi kerja dalam organisasi".

Senada dengan pendapat di atas, Moskowits dikutip dari Hasibuan (2016:96) mengungkapkan bahwa "motivasi merupakan daya penggerak dan pendorong yang ada dalam diri manusia untuk mengerjakan sesuatu sebaik mungkin. Apabila seseorang 
dalam organisasi memiliki motivasi yang tinggi maka kinerja mereka akan tinggi sehingga dapat mewujudkan tujuan yang ingin dicapai. Jadi, titik tolak motivasi adalah individu karena motivasi berada pada setiap individu."

Mencermati pendapat para ahli di atas, motivasi memiliki peran krusial dalam organisasi, tanpa adanya motivasi tidak ada seorang pun yang akan melakukan tindakan dalam organisasi. Konsep motivasi lainnya diungkapkan oleh Maslow dalam Teori Hierarki Kebutuhan dikutip oleh Sutrisno (2009:132), diungkapkan bahwa seseorang termotivasi oleh hasrat untuk memenuhi kebutuhannya yang terbagi dan diklasifikasikan kedalam lima hierarki kebutuhan sebagai berikut : kebutuhan mendasar adalah upah atau gaji, kebutuhan selanjutnya adalah rasa aman yang berhubungan langsung dengan pekerjaannya seperti masa kerja dan pensiun, kebutuhan rasa memilki tercermin pada keanggotaan induvidu pada kelompok formal maupun informal, kebutuhan harga diri ditandai dengan adanya gelar, status atau jabatan dan terkahir kebutuhan aktualisasi diri terlihat pada keinginan untuk berprestasi. Sehingga dapat disimpulkan bahwa Motivasi kerja adalah dorongan yang tumbuh dalam diri seseorang, baik yang berasal dari dalam dan maupun dari luar untuk melakukan suatu pekerjaan dengan semangat tinggi menggunakan semua kemampuan dan keterampilan yang dimiliknya. Dampak dari motivasi kerja adalah terciptanya gairah kerja pegawai.

Instansi pemerintah yang didalamnya terdiri dari banyak orang, dapat dipastikan masing-masing orang tersebut memiliki tujuan tertentu dan dengan adanya tujuan tertentu dapat mendorong dan memotivasi induvidu - induvidu untuk terlibat dalam organisasi, sebagaimana tujuan dari orang bekerja antara lain untuk memenuhi kebutuhan hidupnya terlepas dari apa dan bagaimana jenis dan kebutuhan yang ingin dipenuhi. Sebagimana diungkapkan Hasibuan (2017:146), tujuan dari motivasi antara lain :

1. Mendorong gairah dan semangat kerja pegawai

2. Meningkatkan moral dan kepuasan kerja pegawai

3. Meningkatkan produktivitas kerja pegawai

4. Mempertahankan kestabilan pegawai

5. Meningkatkan kedisiplinan pegawai

6. Mengefektifkan pengadaan pegawai

7. Menciptakan suasana dan hubungan kerja yang baik

8. Meningkatkan loyalitas, kreatifitas dan partisipasi pegawai

9. Meningkatkan tingkat kesejahteraan pegawai

10. Mempertinggi rasa tanggung jawab pegawai terhadap tugastugasnya

11. Meningkatkan efisensi penggunaan alat-alat dan bahan baku.

Adapun berkaitan dengan penelitian ini, peneliti membatasi pada Teori Motivasi yang diungkapkan oleh David C. McClelland (Mc. Clelland's Achievement Theory) karena dianggap paling sesuai. David Mc. Clelland mengungkapkan dalam Hasibuan (2016:103), ada 3 faktor pendorong motivasi : 
a. Motivasi Prestasi

Adalah dorongan dalam diri induvidu untuk mengatasi segala tantangan dan hambatan dalam upaya untuk maju, berkembang dan berhasil mencapai tujuan. Atau dengan kata lain merupakan daya penggerak yang memotivasi semangat kerja seseorang untuk mengembangkan kreativitas dan mengarahkan semua kemampuan serta energi yang dimilikinya demi mencapai prestasi kerja yang optimal.

b. Motivasi Kekuasaan

Adalah dorongan atau kebutuhan untuk mengendalikan lingkungan, mempengaruhi perilaku orang lain dengan cara menyarankan, membujuk atau memerintah. Atau dengan kata lain merupakan Daya penggerak yang merangsang dan memotivasi gairah kerja seseorang serta mengerahkan semua kemampuan demi mencapai kekuasaan atau kedudukan yang terbaik dalam organisasi.

c. Motivasi Afiliasi

Adalah dorongan atau kebutuhan kontak sosial, yaitu kebutuhan untuk menarik orang lain agar lebih dekat dan mau bekerja sama atau bergabung untuk melakukan berbagai hal besama - sama.

\section{Komitmen Organisasi}

Komitmen organisasi menurut Robbins (2001:40) dapat didefinisikan sebagai tujuan Pegawai terhadap organisasi terhadap bentuk identifikasi loyalitas mereka dan keterlibatan mereka di dalam organisasi. Lebih lanjut Steers (1997:11) menjelaskan bahwa "komitmen organisasi merupakan : komitmen sebagai rasa kepercayaan terhadap nilai-nilai organisasi, keterlibatan dan bersedia berusaha sebaik mungkin demi organisasi serta loyalitas atau keinginan untuk tetap menjadi anggota dari organisasi, yang dinyatakan seorang anggota terhadap organisasinya". Sejalan dengan apa yang diungkap oleh Steers, Luthans dikutip Widiana (2015:30) mendefinisikan komitmen terhadap organisasi sebagai berikut:

1. Komitmen adalah keinginan yang kuat untuk menjadi anggota organisasi tertentu.

2. Komitmen adalah kemauan untuk menggunakan usaha yang lebih besar untuk keperluan organisasi.

3. Komitmen adalah keyakinan yang pasti terhadap nilai nilai dan tujuan suatu organisasi.

Dari semua definisi yang telah di paparkan oleh ahli di atas, dapat dijelaskan bahwa komitmen organisasi merupakan kepercayaan dari induvidu yang kuat pada organisasi dengan menerima nilai dan tujuan dari organisasi serta berupaya untuk memberikan hasil yang terbaik demi kepentingan organisasi dan berkeinginan untuk tetap berada dalam organisasi tersebut.

Menurut Allen and Meyer dikutip Umam (2010:259-260) bahwa "ada tiga komponen yang mempengaruhi komitmen organisasi, sehingga Pegawai memilih tetap atau meninggalkan organisasi berdasar norma yang dimilikinya. Tiga komponen tersebut adalah :

1. Komitmen afektif (affective commitment).

Komitmen afektif berkaitan dengan adanya keinginan untuk terikat pada organisasi. Individu menetap dalam organisasi karena keinginan sendiri. Kunci dari 
komitmen ini adalah want to.

2. Komitmen berkelanjutan (continuance commitment).

Komitmen berkelanjutan adalah suatu komitmen yang didasarkan akan kebutuhan rasional. Dengan kata lain, komitmen ini terbentuk atas pertimbangan tentang apa yang harus diberikan bila akan menetap pada suatu organisasi.

3. Komitmen normatif (normative commitment).

Komitmen normatif adalah komitmen yang didasarkan pada norma yang ada dalam diri Pegawai, berisi keyakinan individu akan tanggung jawab terhadap organisasi. Ia merasa harus bertahan karena loyalitas".

Adapun berkaitan dengan penelitian ini, peneliti membatasi pada Teori komitmen organisasi yang diungkapkan oleh Michael Armstrong karena dianggap paling sesuai. Komitmen organisasi menurut Armstrong dikutip Widiana (2015:38) dengan indikator sebagai berikut :

1. Adanya perasaan menjadi bagian dari organisasi (a sense of belonging to the organization)

2. Adanya ketertarikan atau kegairahan terhadap pekerjaan ( $a$ sense of excitement in the job)

3. Adanya rasa memiliki terhadap manajemen (a sense of ownership).

\section{Displin Kerja}

Disiplin merupakan salah satu kunci keberhasilan sebuah organisasi dalam mencapai tujuannya. Nitisemito (2015:60) mengemukakan pengertian disiplin, "yakni dalam arti sempit dan arti luas. Dalam arti sempit dikatakan bahwa disiplin adalah bilamana pegawai tersebut jarang absen dan datang serta pulang tepat pada waktunya. sedangkan dalam arti luas disiplin diartikan sebagai suatu sikap, tingkah laku dan perbuatan yang sesuai dengan peraturan dari perusahaan baik yang tertulis maupun tidak". Lebih lanjut diungkapkan oleh Hasibuan (2017:193), bahwa "Kedisiplinan adalah kesadaran dan kesediaan seseorang menaati semua peraturan organisasi dan norma-norma sosial yang berlaku. Kesadaran adalah sikap seseorang yang secara sukarela menanti semua peraturan dan sadar akan tugas dan tanggung jawabnya". Dari penjelasan tersebut dapat dikatakan bahwa Disiplin adalah suatu kondisi yang terbentuk melalui proses perilaku, pelajaran, ketaatan dan norma yang berlaku. Disiplin kerja sangat diperlukan dalam suatu organisasi pemerintah maupun swasta. Suatu organisasi ditentukan oleh disiplin para pegawainya. Wujud disiplin yang nyata dapat dilihat dari sikap dan perilaku pegawai.

Sutrisno mengungkapkan bahwa disiplin kerja adalah sikap kesediaan dan kerelaan seseorang untuk mematuhi dan mentaati norma-norma peraturan yang berlaku disekitarnya. Senada dengan hal tersebut, Davis dalam Mangkunegara (2013:129) mengemukakan bahwa "disiplin kerja dapat diartikan sebagai pelaksanaan suatu organsisi untuk memperteguh pedoman-pedoman organisasi. Disiplin timbul dari dalam diri seseorang. Disiplin adalah suatu kondisi yang terbentuk melalui proses perilaku, pelajaran, ketaatan dan norma yang berlaku." Dengan disiplin yang tinggi tujuan organisasi dapat diwujudkan sebagaimana yang diharapkan. 
Disiplin kerja pegawai berdampak positif terhadap kinerja sebuah organisasi. Jika disiplin kerja tinggi, dengan sendirinya efektivitas dan efisiensi pun tinggi, sekaligus akan tercermin pada kinerja pegawai dan organisasi secara keseluruhan. Sebaliknya jika di dalam satuan kerja efektivitas dan efisiensinya rendah, kinerja pegawai dan organisasinya juga rendah. Oleh karena itu, setiap pemimpin organisasi selalu berusaha agar anggotanya mempunyai disiplin kerja yang baik. Seorang pemimpin dikatakan efektif dalam kepemimpinannya, jika para anggotanya bedisiplin baik. Untuk memelihara dan meningkatkan kedisplinan yang baik adalah hal yang sulit, karena banyak faktor yang mempengaruhinya. Seorang pemimpin dalam organisasi mempunyai pengaruh langsung terhadap sikap, tingkah laku, kebiasaan serta tingkat disiplin para pegawai pada organisasi tersebut.

Hasibuan

(2017:195-196)

mengungkapkan faktor - faktor yang mempengaruhi tingkat disiplin Pegawai suatu organisasi, diantaranya adalah :

\section{Tujuan dan Kemampuan}

Tujuan dan kemampuan ikut mempengaruhi tingkat kedisiplinan Pegawai. Pencapaian tujuan harus jelas dan ditetapkan secara ideal serta memacu kinerja pegawai dalam kemampuan bekerja. Hal ini menjelaskan bahwa pekerjaan yang dibebankan kepada pegawai harus sesuai dengan kemampuan yang dimiliki pegawai, agar dapat bekerja dengan baik dan disiplin dalam mengerjakannya.

2. Teladan Pimpinan

Teladan pimpinan sangat berperan dalam menentukan kedisiplinan
Pegawai karena pimpinan dijadikan contoh oleh para pegawainya. Pimpinan harus membri contoh yang baik, berdisiplin baik dan adil.

3. Balas Jasa

Balas jasa (gaji dan kesejahteraan) dapat mempengaruhi kedisplinan Pegawai, karena balas jasa akan memberikan kepuasan dan kecintaan pegawai terhadap suatu pekerjaannya. Jika kecintaan pegawai pada pekerjaan semakin baik, kualitas pelayananan mereka akan semakin baik juga.

4. Keadilan

Keadilan memiliki kontribusi dalam terwujudnya disiplin pegawai, karena sifat manusia yang merasa dirinya ingin di anggap penting dan diperlalkukan sama dengan manusia lainnya. Keadilan yang dijadikan dasar kebijaksanaan dalam pemberian balas jasa atau hukuman akan merangsang terciptanya Kualitas pelayananan pegawai. Pemimpin yang cakap dalam memimpin selalu bebeusaha bersikap adil terhadap semua bawahannya. Dengan keadilan yang baik akan menciptakan kedisiplinan yang baik juga.

5. Pengawasan Melekat (waskat) Waskat adalah tindakan nyata dan paling efisien dalam mewujudkan kualitas pelayanan pegawai. Dengan waskat berarti atasan harus aktif dan langsung mengawasi perilaku, moral, sikap, gairah kerja dan prestasi kerja bawahanya. Waskat menuntut adanya kebersamaan aktif antara atasan dan bawahan dalam mencapai tujuan. Waskat efektif merangsang kedisiplinan dan moral pegawai.

6. Sanksi Hukuman 
Sanksi hukum berperanan penting dalam memelihara kualitas pelayananan pegawai, dengan sanksi yang semakin berat, pegawai akan semakin takut melanggar peraturan. Sanksi hukuman harus ditetapkan berdasarkan pertimbangan logis, masuk akal dan dinformasikan secara jelas kepada semua pegawai.

7. Ketegasan

Ketegasan pimpinan dalam melakukan tindakan akan mempengaruhi kualitas pelayananan pegawai. Pimpinan harus berani dan tegas, bertindak untuk menghukum setiap pegawai yang kualitas pelayanan tidak sesuai dengan SOP.

8. Hubungan Kemanusiaan

Hubungan kemanusiaan yang harmonis di antara pegawai ikut menciptakan kualitas pelayanan yang baik. Hubungan-hubungan baik bersifat vertikal maupun horizontal hendaknya harmonis.

Disiplin kerja yang baik akan mencerminkan besarnya tanggung jawab seseorang terhadap tugas-tugas yang diberikan kepadanya. Hal ini mendororng gairah kerja, semangat kerja, dan terwujudnya tujuan organsisasi. Berkaitan dengan penelitian ini, peneliti menggunakan indikator yang diungkapkan oleh Singodimejo dikutip Sutrisno (2011:94) sebagai berikut :

1. Taat terhadap aturan waktu, dapat diartikan sebagai sikap atau tingkah laku yang menunjukkan ketaatan terhadap jam kerja yang meliputi kehadiran dan kepatuhan pegawai pada jam kerja serta pegawai dapat melaksanakan tugas dengan tepat waktu dan benar.
2. Taat terhadap peraturan organisasi, peraturan maupun tata tertib yang tertulis dan tidak tertulis di buat agar tujuan suatu organisasi dapat tercapai, sehingga dibutuhkan komitmen dari pegawai atas aturan yang telah ditetapkan tersebut.

3. Taat terhadap aturan perilaku dalam pekerjaan, ditunjukkan dengan cara melakukan pekerjaan - pekerjaan sesuai dengan jabatan, tugas dan tanggung jawab serta berhubungan dengan unit kerja lain.

4. Taat terhadap peraturan lainnya di organisasi, aturan tentang apa yang boleh dan apa yang tidak boleh dilakukan pegawai dalam organisasi.

\section{B. Metode Penelitian}

Metode Penelitian dalam penelitian ini menggunakan metode kuantitatif dengan penelitian survey. Dalam penelitian ini, peneliti melakukan penelitian pada 13 Kantor Kecamatan di Kota Tangerang untuk memperoleh data yang berhubungan dengan penelitian ini. Data yang diperoleh akan dianalisis menggunakan uji statistik untuk menemukan fakta dari masing masing variabel yang diteliti serta untuk mengetahui hubungan antara variabel bebas (Kepemimpinan, Motivasi Kerja, Komitmen Organisasi) dengan variabel terikat (Disiplin Kerja).

Dalam penelitian ini, teknik
yang peneliti gunakan dalam
menentukan sampel adalah dengan
teknik Cluster Sampling yaitu dengan
memilih sampel dari kelompok -
kelompok unit yang kecil. Adapun
dengan Populasi yang tersebar di 13
Kecamatan di Kota Tangerang,


peneliti membagi populasi menjadi kluster dan mengambil secara acak untuk di gunakan sebagai sampel.

Responden yang menjadi objek dalam penelitian ini adalah Aparatur Sipil Negara di Kecamatan se - Kota Tangerang yang berjumlah 920 orang ASN. Jumlah populasi tersebut dengan menggunakan rumus Slovin maka yang dijadikan sampel sebanyak 90 Orang Aparatur Sipil Negara Kecamatan di Kota Tangerang dimana dengan menggunakan sarana angket kuestioner yang berisi daftar pertanyaan/pernyataan diharapkan dapat memberikan gambaran yang nyata, keadaan sesungguhnya dan mendekati fakta yang ada.

\section{Hasil Penelitian dan Pembahasan}

Analisa responden dilakukan untuk mendeskripsikan karakteristik data induvidu yang meliputi : Jenis kelamin, Usia, Tingkat Pendidikan dan Masa Kerja Responden. Deskripsi karakteristik responden dalam penelitian ini menunjukkan Responden untuk jenis kelamin pada penelitian ini untuk pria sebanyak 69 orang dengan presentase $67 \%$ dan untuk perempuan sebanyak 21 orang dengan presentase 23\%. Di jenjang pendidikan, responden berpendidikan SLTA sebanyak 22 orang dengan persentase $20 \%$ dan jenjang pendidikan sarjana dan pascasarjana sebanyak 68 orang dengan persentase $80 \%$. Untuk usia responden cukup bervariatif, usia 21 s.d 30 tahun berjumlah 12 orang dengan presentase $13 \%$, usia 31 s.d 40 tahun berjumlah 40 orang dengan presentase $44 \%$, usia 41 s.d 50 tahun berjumlah 23 orang dengan persentase $26 \%$, dan usia 51 s.d 60 tahun berjumlah 15 orang dengan presentase $16 \%$. Sedangkan untuk masa kerja, responden yang masa kerjanya 1 s.d 15 tahun sebanyak 45 orang dengan persentase $50 \%$, responden dengan masa kerja 15 s.d 30 tahun sebanyak 32 orang dengan persentase $36 \%$, dan responden dengan masa kerja 31 s.d 45 tahun sebanyak 13 orang dengan persentase $14 \%$.

\section{Hubungan Kepemimpinan dengan Disiplin Kerja ASN Kecamatan di Kota Tangerang}

Hipotesis pertama dalam penelitian ini adalah diduga terdapat hubungan antara Kepemimpinan dengan Disiplin Kerja Aparatur Sipil Negara Kecamatan di Kota Tangerang. Hasil perhitungan korelasi variabel Kepemimpinan $\left(\mathrm{X}_{1}\right)$ dengan Disiplin Kerja (Y) menunjukkan koefisien korelasi sebesar 0,727 dengan nilai signifikansi sebesar $0,000<0,05$. Kemudian nilai korelasi tersebut dimasukan kedalam rumus $\mathrm{t}$ hitung, dimana hasil perhitungan $t$ hitung didaptkan nilai 9,935 nilai tersebut apabila dibandingkan dengan nilai $\mathrm{t}$ tabel dengan sampel 90 responden yaitu sebesar 1,987 pada taraf signifikansi 0,05 sehingga nilai $t$ hitung lebih besar dari pada nilai $\mathrm{t}$ tabel. Berdasarkan hasil uji t tersebut maka pengujian hipotesis $\mathrm{H}_{0}$ ditolak dan Ha diterima. Sehingga hipotesis penelitian yang menyatakan terdapat Hubungan antara Kepemimpinan dengan Disiplin Kerja ASN Kecamatan di Kota Tangerang dapat diterima kebenarannya. Adapun berdasarkan hasil pengujian Koefisien Determinasi untuk mengetahui kontribusi variabel Kepemimpinan 
$\left(\mathrm{X}_{1}\right)$ dengan Disiplin Kerja (Y) ASN Kecamatan di Kota Tangerang diperoleh nilai sebesar 52,9\%.

Hipotesis Penelitian ini sejalan dengan hasil penelitian yang dilakukan oleh Aan Parawangsyah, Muh. Alwy Arifin dan Nurhayani dari Universitas Hasanuddin Makassar dalam jurnal ilmiah di tahun 2012 yang berjudul Hubungan Gaya Kepemimpinan Terhadap Disiplin Kerja Tenaga Kesehatan Di Puskesmas Batua. Hasil analisis bivariat menunjukkan bahwa terdapat hubungan antara gaya kepemimpinan berdasarkan pemecahan masalah dengan disiplin kerja tenaga kesehatan. Dalam teori lain, Farland menjelaskan "kepemimpinan merupakan sebuah proses proses yang didalamnya pemimpin memberi perintah atau pengaruh, bimbingan atau proses mempengaruhi pekerjaan orang lain dalam memilih dan mencapai tujuan yang telah ditetapkan" (Danim, 2010:6). Dengan kata lain, dapat dikatakan bahwa kepemipinan merupakan salah satu faktor yang berhubungan dengan disiplin kerja ASN Kecamatan di Kota Tangerang.

Dengan demikian dapat disimpulkan bahwa terdapat hubungan signifikan secara statistik antara Kepemimpinan dengan Disiplin Kerja ASN Kecamatan di Kota Tangerang yang positif. Artinya apabila variabel Kepemimpinan terutama yang berkaitan dengan indikator kemampuan pengawasan meliputi pimpinan menentukan proses pelaksanaan pekerjaan dan mengevaluasi pekerjaan pegawai ditingkatkan, indikator Kesuksesan dalam pekerjaan meliputi pengaturan pegawai untuk bekerja lebih baik dan perencanaan tujuan organisasi ditingkatkan, Indikator Intelektual meliputi kematangan pola pikir dan Inovasi pimpinan ditingkatkan, Indikator Kepercayaan diri meliputi optimisme pimpinan ditingkatkan, Indikator Inisiatif meliputi pengambilan keputusan dan inisatif dalam melaksanakan tugas ditingkatkan maka akan meningkatkan Disiplin Kerja ASN Kecamatan di Kota Tangerang. Sehingga dapat dikatakan bahwa, semakin tinggi tingkat Kepemimpinan maka akan semakin tinggi Disiplin Kerja ASN Kecamatan di Kota Tangerang.

\section{Hubungan Motivasi Kerja dengan Disiplin Kerja ASN Kecamatan di Kota Tangerang}

Hipotesis kedua dalam penelitian ini adalah diduga terdapat hubungan antara Motivasi Kerja dengan Disiplin Kerja Aparatur Sipil Negara Kecamatan di Kota Tangerang. Hasil perhitungan korelasi variabel Motivasi Kerja $\left(\mathrm{X}_{2}\right)$ dengan Disiplin Kerja (Y) menunjukkan koefisien korelasi sebesar 0,842 dengan nilai signifikansi sebesar $0,000<0,05$. Kemudian nilai korelasi tersebut dimasukan kedalam rumus t hitung, dimana hasil perhitungan $\mathrm{t}$ hitung didapatkan nilai 14,630 nilai tersebut apabila dibandingkan dengan nilai $t$ tabel dengan sampel 90 responden yaitu sebesar 1,987 pada taraf signifikansi 0,05 sehingga nilai $t$ hitung lebih besar dari pada nilai $t$ tabel. Berdasarkan hasil uji t tersebut maka pengujian hipotesis $\mathrm{H}_{0}$ ditolak dan Ha diterima. Sehingga hipotesis penelitian yang menyatakan terdapat Hubungan antara Motivasi Kerja dengan Disiplin Kerja ASN 
Kecamatan di Kota Tangerang dapat diterima kebenarannya. Adapun berdasarkan hasil pengujian Koefisien Determinasi untuk mengetahui kontribusi variabel Motivasi Kerja $\left(\mathrm{X}_{2}\right)$ dengan Disiplin Kerja (Y) ASN Kecamatan di Kota Tangerang diperoleh nilai sebesar 71,6\%.

Hipotesis Penelitian ini sejalan dengan teori yang disampaikan Thoha (2014:253) bahwa Motivasi merupakan pendorong agar seseorang itu melakukan suatu kegiatan untuk mencapai tujuannya. Motivasi sebagai kekuatan yang membuat seseorang berkeinginan memulai dan menjaga kondisi kerja dalam organisasi. Senada dengan pendapat di atas, Moskowits dikutip dari Hasibuan (2016:96) mengungkapkan bahwa "motivasi merupakan daya penggerak dan pendorong yang ada dalam diri manusia untuk mengerjakan sesuatu sebaik mungkin. Apabila seseorang dalam organisasi memiliki motivasi yang tinggi maka kinerja mereka akan tinggi sehingga dapat mewujudkan tujuan yang ingin dicapai. Dari pendapat ahli tersebut, peneliti berkesimpulan bahwa menjaga motivasi kerja merupakan salah satu faktor yang berhubungan dengan disiplin kerja ASN Kecamatan di Kota Tangerang. Dengan motivasi kerja yang baik, ASN mampu bertanggung jawab terhadap tugasnya, meningkatkan kreativitas dan patisipasinya dalam pekerjaan dan motivasi kerja juga dapat meningkatkan kedisiplinan ASN.

$$
\text { Dengan demikian dapat }
$$

disimpulkan bahwa terdapat hubungan signifikan secara statistik antara Motivasi Kerja dengan Disiplin Kerja ASN Kecamatan di Kota Tangerang yang positif. Artinya apabila variabel Motivasi Kerja terutama yang berkaitan dengan indikator Motivasi Prestasi meliputi Pemberian penghargaan/reward, kesempatan mengembangan kompetensi, penilaian kinerja dan penyelesain pekerjaan tepat waktu ditingkatkan, Indikator Motivasi Afiliasi meliputi turut serta dalam kegiatan penting, teamwork/kerjasama, hubungan sosial dan keteladaan ditingkatkan, dan Indikator Motivasi Kekuasaan meliputi kewenangan dan musyawarah dalam mengambil keputusan ditingkatkan maka akan meningkatkan Disiplin Kerja ASN Kecamatan di Kota Tangerang. Sehingga dapat dikatakan bahwa, semakin tinggi Motivasi Kerja maka akan semakin tinggi Disiplin Kerja ASN Kecamatan di Kota Tangerang.

\section{Hubungan Komitmen Organisasi dengan Disiplin Kerja ASN Kecamatan di Kota Tangerang} Hipotesis ketiga dalam penelitian ini adalah diduga terdapat hubungan antara Komitmen Organisasi dengan Disiplin Kerja Aparatur Sipil Negara Kecamatan di Kota Tangerang. Hasil perhitungan korelasi variabel Komitmen Organisasi $\left(\mathrm{X}_{3}\right)$ dengan Disiplin Kerja (Y) menunjukkan koefisien korelasi sebesar 0,660 dengan nilai signifikansi sebesar $0,000<0,05$. Kemudian nilai korelasi tersebut dimasukan kedalam rumus $\mathrm{t}$ hitung, dimana hasil perhitungan $\mathrm{t}$ hitung didapatkan nilai 8,247 nilai tersebut apabila dibandingkan dengan nilai $\mathrm{t}$ tabel dengan sampel 90 responden yaitu sebesar 1,987 pada taraf signifikansi 0,05 sehingga nilai $t$ hitung lebih besar dari pada nilai $\mathrm{t}$ tabel. Berdasarkan hasil uji t tersebut 
maka pengujian hipotesis $\mathrm{H}_{0}$ ditolak dan Ha diterima. Sehingga hipotesis penelitian yang menyatakan terdapat Hubungan antara Komitmen Organisasi dengan Disiplin Kerja ASN Kecamatan di Kota Tangerang dapat diterima kebenarannya. Adapun berdasarkan hasil pengujian Koefisien Determinasi untuk mengetahui kontribusi variabel Komitmen Organisasi $\left(\mathrm{X}_{3}\right)$ dengan Disiplin Kerja (Y) ASN Kecamatan di Kota Tangerang diperoleh nilai sebesar $43,6 \%$.

Hipotesis Penelitian ini sejalan dengan penelitian yang di lakukan oleh Galih Septian dari Universitas Pendidikan Indonesia pada tahun 2014 yang berjudul Pengaruh Komitmen Organisasi Terhadap Disiplin Kerja ASN Negeri Sipil Pada Badan Kepegawaianan di Kota Cimahi. Hasil penelitian menunjukkan bahwa adanya pengaruh yang positif dan signifikan antara Komitmen Organisasi dengan variabel Disiplin Kerja ASN. Hal ini juga menjelaskan bahwa Disiplin ASN akan baik ketika Komitmen para ASN terbentuk dengan baik. Disamping itu, lebih lanjut oleh Miftachul Mujib dan Setyabudi Indartono dari Universitas Negeri Yogyakarta dalam Jurnal Ilmiah pada tahun 2016 yang berjudul Pengaruh Lingkungan Kerja Dan Komitmen Terhadap Disiplin Kerja (Studi Pada Pegawai Badan Kepegawaian Daerah DIY). Hasil penelitian menunjukkan bahwa Komitmen berpengaruh positif terhadap disiplin pegawai. Kontribusi pengaruh lingkungan kerja dan komitmen berpengaruh positif terhadap disiplin kerja pegawai sebesar 0,066 .

Dengan demikian dapat disimpulkan bahwa terdapat hubungan signifikan secara statistik antara Komitmen Organisasi dengan Disiplin Kerja ASN Kecamatan di Kota Tangerang yang positif. Artinya apabila variabel Komitmen Organisasi terutama yang berkaitan dengan indikator perasaan menjadi bagian dari organisasi meliputi rasa bagian dari instansi, rasa ikut memiliki instansi dan loyalitas terhadap instansi ditingkatkan, Indikator Ketertarikan atau kegairahan terhadap pekerjaan meliputi semangat dalam bekerja, bekerja sungguh - sungguh dan senang melaksanakan tugas ditingkatkan serta Indikator Rasa memiliki manajemen meliputi kontribusi untuk instansi, pengabdian terhadap instansi, patuh terhadap keputusan instansi dan berkomitmen terhadap pekerjaan ditingkatkan maka akan meningkatkan Disiplin Kerja ASN Kecamatan di Kota Tangerang. Sehingga dapat dikatakan bahwa, semakin tinggi Komitmen Organisasi maka akan semakin tinggi Disiplin Kerja ASN Kecamatan di Kota Tangerang.

\section{Hubungan Kepemimpinan, Motivasi Kerja dan Komitmen Organisasi dengan Disiplin Kerja ASN Kecamatan di Kota Tangerang}

Hipotesis keempat dalam penelitian ini adalah diduga terdapat hubungan antara Kepemimpinan, Motivasi Kerja dan Komitmen Organisasi dengan Disiplin Kerja Aparatur Sipil Negara Kecamatan di Kota Tangerang. Hasil perhitungan korelasi berganda diperoleh nilai koefisien korelasi berganda sebesar 0,889 dan dengan menggunakan Uji Simultan (Uji F) untuk membuktikan hipotesis didapatkan nilai Fhitung sebesar 108,512. Nilai tersebut lebih besar dari nilai Ftabel pada taraf 
signifikansi 5\% sebesar 2,71. Dari hasil uji simultan dapat disimpulkan Ho ditolak dan Ha diterima. Sehingga hipotesis penelitian yang menyatakan terdapat Hubungan antara Kepemimpinan, Motivasi Kerja dan Komitmen Organisasi secara bersama sama dengan Disiplin Kerja ASN Kecamatan di Kota Tangerang dapat diterima kebenarannya. Dari hasil analisis koefisien determinasi diperoleh informasi secara bersamaan bahwa variabel Kepemimpinan $\left(\mathrm{X}_{1}\right)$, Motivasi Kerja $\left(\mathrm{X}_{2}\right)$, dan Komitmen Organisasi $\left(\mathrm{X}_{3}\right)$ dengan Disiplin Kerja (Y) ASN Kecamatan di Kota Tangerang berkontribusi sebesar $79,1 \%$, dan sebesar $20,9 \%$ dijelaskan oleh variabel lain yang tidak diteliti dalam penelitian ini. Dengan demikian dapat disimpulkan bahwa terdapat hubungan signifikan secara statistik antara Kepemimpinan, Motivasi Kerja dan Komitmen Organisasi secara bersama-sama dengan Disiplin Kerja ASN Kecamatan di Kota Tangerang yang positif.

Adapun berdasarkan

perhitungan yang dilakukan dalam penelitian ini, didapatkan persamaan $\mathrm{Y}=0,394+0,252 \mathrm{X} 1+0,557 \mathrm{X} 2+$ 0,219X3. Persamaan tersebut menunjukkan bahwa nilai koefisien variabel kepemimpinan $\left(\mathrm{X}_{1}\right)$ sebesar 0,252 artinya, apabila kepemimpinan $\left(\mathrm{X}_{1}\right)$ meningkat 1 poin maka Disiplin Kerja (Y) akan meningkat sebesar 0,252 poin dengan asumsi $X_{2}$ dan $X_{3}$ tetap. Koefisien variabel Motivasi Kerja $\left(\mathrm{X}_{2}\right)$ sebesar 0,557 artinya apabila Motivasi Kerja $\left(\mathrm{X}_{2}\right)$ meningkat 1 poin maka maka Disiplin Kerja (Y) akan meningkat sebesar 0,557 poin, dengan asumsi $\mathrm{X}_{1}$ dan $\mathrm{X}_{3}$ tetap. Koefisien variabel komitmen organisasi $\left(\mathrm{X}_{3}\right)$ sebesar 0,219 artinya apabila Komitmen Organisasi $\left(\mathrm{X}_{3}\right)$ meningkat 1 poin maka Disiplin Kerja (Y) akan meningkat sebesar sebesar 0,219 poin, dengan asumsi $X_{1}$ dan $X_{2}$ tetap.

Dari hasil penelitian ini, didapatkan informasi bahwa variabel yang memiliki hubungan paling kuat terhadap Disiplin Kerja ASN Kota Tangerang yaitu Variabel Motivasi dengan nilai koefisien variabel sebesar 0,557, Motivasi Kerja yang tinggi akan membuat Disiplin Kerja ASN Kecamatan di Kota Tangerang meningkat. Salah satunya dengan adanya tunjangan berbasis kinerja sebagai pelaksanaan dari sistem reward and pusnihment agar memotivasi pegawai dalam disiplin kerja. Dimana pegawai yang berdisiplin diberikan reward (penghargaan) yang pantas dan bagi pegawai yang melanggar disiplin diberikan punishment (hukuman) yang sesuai dengan tingkat kesalahannya. Adanya pembayaran tunjangan berbasis kinerja ini, akan membantu meningkatkan disiplin kerja pegawai yang secara simultan dan meningkatkan kembali motivasi kerja ASN. Selanjutnya, variabel Kepemimpinan dengan nilai koefisien variabel sebesar 0,252, dengan Kepemimpinan yang kuat akan meningkatkan Disiplin Kerja ASN Kecamatan di Kota Tangerang. Terakhir adalah variabel Komitmen Organisasi, dengan nilai koefisien variabel sebesar 0,219. Meskipun menempati hubungan yang paling rendah dibandingkan dengan variabel yang lain akan tetapi dengan komitmen organisasi yang tinggi akan membuat Displin Kerja ASN Kecamatan di Kota Tangerang 
meningkat karena adanya rasa memiliki terhadap instansi sehingga ASN menjadi loyal untuk organisasi. Hal ini sekaligus akan tercermin pada kinerja ASN dan organisasi di Kecamatan secara keseluruhan.

\section{Kesimpulan}

Bertitik tolak dari hasil penelitian dan pembahasan tentang hubungan antara Kepemimpinan, Motivasi Kerja dan Komitmen Organisasi dengan Disiplin Kerja ASN Kecamatan Kota Tangerang dapat ditarik kesimpulan sebagai berikut :

1. Terdapat hubungan antara kepemimpinan dengan disiplin kerja ASN Kecamatan di Kota Tangerang. Hasil pengujian secara statistik menunjukkan bahwa terdapat hubungan signifikan secara statistik antara kepemimpinan dengan disiplin kerja ASN Kecamatan di Kota Tangerang yang positif sebesar 0,727 .

2. Terdapat hubungan antara motivasi kerja dengan disiplin kerja ASN Kecamatan di Kota Tangerang. Hasil pengujian secara statistik menunjukkan bahwa terdapat hubungan signifikan secara statistik antara motivasi kerja dengan disiplin kerja ASN Kecamatan di Kota Tangerang yang positif sebesar 0,842 .

3. Terdapat hubungan antara komitmen organisasi dengan disiplin kerja ASN Kecamatan di Kota Tangerang. Hasil pengujian secara statistik menunjukkan bahwa terdapat hubungan signifikan secara statistik antara komitmen organisasi dengan disiplin kerja ASN Kecamatan di Kota Tangerang yang positif Vol 2, No 1 (2020) sebesar 0,660.

4. Terdapat hubungan antara kepemimpinan, motivasi kerja dan komitmen organisasi secara bersama - sama dengan disiplin kerja ASN Kecamatan di Kota Tangerang. Hasil pengujian secara statistik menunjukkan bahwa Terdapat hubungan signifikan secara statistik antara kepemimpinan, motivasi kerja dan komitmen organisasi secara bersama - sama dengan disiplin kerja ASN Kecamatan di Kota Tangerang yang positif sebesar 0,889 .

Memperhatikan hasil analisis penelitian yang telah peneliti lakukan dalam penelitian ini, sebagai upaya untuk meningkatakan Disiplin Kerja ASN Kecamatan di Kota Tangerang direkomendasikan hal - hal sebagai berikut :

1. Untuk Pemimpin Kecamatan

Kepemimpinan, Motivasi Kerja dan Komitmen Organisasi dapat memberikan kontribusi positif bagi disiplin kerja ASN kecamatan di Kota Tangerang. Oleh karena itu diperlukan upaya peningkatan dari kualitas manajerial pemimpin seperti memberi contoh yang baik bagi pegawainya, pemimpin mampu melaksanakan fungsi pengawasan kepada setiap ASN di bawah kendalinya dan pemimpin juga harus mampu membangun komunikasi yang baik dan memberikan reward kepada ASN yang berprestasi serta memberi sanksi atau hukuman bagi setiap pelanggaran pelanggaran yang terjadi.

2. Untuk para ASN

Dengan adanya tunjangan berbasis 
kinerja bagi pegawai ASN di kota tangerang diharapkan ASN mampu memotivasi kinerjamya yang lebih baik diwujudkan dengan rutin hadir di apel pagi, datang dan pulang kerja pada waktunya, tanggung jawab terhadap pekerjaan, serta mampu memacu semangat rekan - rekan ASN disekitarnya. Serta perwujudan dari Komitmen Organisasi dengan dibuktikan dengan keterlibatan ASN dalam setiap kegiatan, baik kegiatan di dalam maupun di luar kecamatan agar ASN merasa bahwa organisasi tempat ASN bekerja saat ini adalah organisasi yang terbaik, sehingga ASN dapat sepenuhnya memberikan pengaruh yang optimal. Bekerja dengan motivasi dan komitmen yang tinggi akan meningkatkan kinerja dan dispilin kerja yang optimal.

3. Untuk Penelitian Selanjutnya

Hasil penelitian ini diharapkan dapat dikembangkan dan dijadikan bahan pertimbangan untuk penelitian - penelitian selanjutnya khususnya yang berkaitan dengan Disiplin Kerja. Selain dari pada itu, diharapkan dilakukan penelitian dan pengkajian lebih lanjut berkaitan dengan variabel lainnya yang belum di teliti dalam penelitian ini, sehingga kedepannya didapatkan gambaran yang utuh berkaitan dengan faktor - faktor lain yang mempengaruhi Disiplin Kerja ASN Kecamatan di Kota Tangerang.

\section{Daftar Pustaka}

\section{Buku:}

Azwar, S. 2009. Metode Penelitian. Yogyakarta: Pustaka Pelajar.

Danim, S. 2010. Kepemimpinan Pendidikan. Bandung: Alfabeta.

Darwati, E., Soegiarto E, K,. dan Lau, E, A,. 2015. 'Pengaruh Kepemimpinan Terhadap Disiplin Kerja Pegawai Negeri Sipil Pada Badan Kepegawaian Daerah Kabupaten Kutai Barat'. Jurnal Ilmiah. Samarinda: Fakultas Ekonomi Universitas 17 Agustus 1945.

Pasalong, H. 2013. Kepemimpinan Birokrasi. Bandung: Alfabeta.

Hasibuan, M. S. P. 2016. Organisasi dan Motivasi. Jakarta: Bumi Aksara.

Hasibuan, M. S. P. 2017. Manajemen Sumber Daya Manusia Edisi Revisi. Jakarta: Bumi Aksara.

Indriyati, E. S. 2017. 'Pengaruh Gaya Kepemimpinan, Motivasi Dan Disiplin Kerja Terhadap Kinerja Karyawan dengan pemahaman etika kerja islami'. Jurnal Upawija Dewantara, Volume 1 (2) hal 134-146.

Kartono, K. 2010. Pemimpin dan Kepemimpinan. Jakarta: PT. Rajawali Grafindo Persada.

Mangkunegara, A. P. 2014. Evaluasi Kinerja Sumber Daya Manusia. Bandung: Refika Aditama.

Mujib, M dan Indartono, S. 2016. 'Pengaruh Lingkungan Kerja Dan Komitmen Terhadap Disiplin Kerja (Studi Pada Pegawai Badan Kepegawaian Daerah DIY)'. Jurnal Prosiding Seminar Nasional. Yogyakarta: Universitas Negeri Yogyakarta.

Nazir. M. 2013. Metode Penelitian. Jakarta: Ghalia Indonesia. 
Nitisemito, A. S. 2015. Manajemen Personalia, Cetakan kedelapan. Jakarta: Ghalia Indonesia.

Parawangsyah, A., Arifin, A., dan Nurhayani. 2012. 'Hubungan Gaya Kepemimpinan Terhadap Disiplin Kerja Tenaga Kesehatan Di Puskesmas Batua Kota Makasar'. Jurnal Ilmiah. Makasar: Universitas Hasanuddin Makassar.

Prasetya, I, at al. 2002. Manajemen Sumber Daya Manusia. Jakarta:STIA - LAN Press.

Rahmawan, R, Y., Kusasi, F., dan Iranita. 2018. 'Pengaruh Kepemimpinan, Disiplin Kerja, Pengembangan Karir Dan Komitmen Organisasi Terhadap Kinerja Pegawai “. Jurnal Ilmiah. Riau: Universitas Maritim Raja Ali Haji.

Robbin, S. P. 2001. Perilaku Organisasi, Konsep, Kontroversi, Aplikasi Jilid I dan II, Edisi Kedelapan. Jakarta: Prenhallindo.

Septian, G. 2014. Pengaruh Komitmen Organisasi Terhadap Disiplin Kerja Pegawai Negeri Sipil Pada Badan Kepegawaian di Kota Cimahi. Skripsi. Bandung: Universitas Pendidikan Indonesia.

Steers, R. M. 1997. Efektivitas Organisasi : Suatu Perilaku Cetakan Ketiga, Terjemahan. Jakarta: Erlangga.

Sugiyono. 2013. Metode Penelitian Kuantitatif, Kualitatif dan R\&D. Bandung: Alfabeta.

Sugiyono. 2017. Metode Penelitian Kuantitatif, Kualitatif dan R\&D. Bandung: Alfabeta.

Suharsono, 2012. Pengetahuan Dasar Organisasi. Jakarta: Universitas Atmajaya.

Sutrisno, E. 2011. Manajemen Sumber Daya Manusia. Jakarta : Kencana.

Syafiie, I. K dan Welasari. 2015. Ilmu Administrasi. Yogyakarta: Pustaka Pelajar

Thoha, M. 2014. Perilaku Organisasi. Jakarta: Rajawali Pers.

Umam, K. 2010. Perilaku Organisasi. Bandung: Pustaka Setia.

Widiana, E. M. 2015. Variabel dan Indikator yang Mempengaruhi Komitmen dan Kinerja Organisasi Pemerintahan. Surabaya: UBHARA Manajemen Press.

\section{Peraturan :}

Undang-Undang Nomor 5 Tahun 2014 Tentang Aparatur Sipil Negara. 2014. Jakarta: Kementrian Pendayagunaan Aparatur Negara dan Reformasi Birokrasi.

Peraturan Pemerintah Nomor 53 Tahun 2010 tentang Disiplin Pegawai Negeri Sipil. 2010. Jakarta: Kementrian Pendayagunaan Aparatur Negara dan Reformasi Birokrasi.

Peraturan Daerah Kota Tangerang Nomor 16 Tahun 2000 tentang Pembentukan 7 Kecamatan. 2000. Tangerang : Pemerintah Kota Tangerang.

Peraturan Daerah Kota Tangerang Nomor 7 Tahun 2008 tentang Organisasi Kecamatan dan Kelurahan Kota Tangerang. 2008. Tangerang : Pemerintah Kota Tangerang.

Peraturan Walikota Tangerang Nomor 82 Tahun 2016 tentang Kedudukan, Susunan Organisasi, Tugas dan Fungsi serta Tata Kerja Kecamatan. 2016. Tangerang : Pemerintah Kota Tangerang

Peraturan Walikota Tangerang Nomor 3 Tahun 2018 tentang Hari Kerja, Jam Kerja dan Apel Pagi. 2018. Tangerang : Pemerintah Kota Tangerang.

\section{Website :}


Novianto, R. D. 2018. BKN Ungkap 2.674 PNS terbukti korupsi, baru 317 yang dipecat. https://nasional.sindonews.com/read/1335541/13/bkn-ungkap-2674pns-terbukti-korupsi-baru-317-yang-dipecat-1536049655 (diunduh 11 Februari 2019)

Penegakan Disiplin PNS dinilai belum maksimal, ini penyebabnya. 2018. https://nasional.sindonews.com/read/1281390/15/penegakan-disiplin-pnsdinilai-belum-maksimal-ini-penyebabnya-1518411884 (diunduh 11 Februari 2019) 